\title{
Firing and Initiation Characteristics of Energetic Semiconductor Bridge Integrated with Varied Thickness of $\mathrm{Al} / \mathrm{MoO}_{3}$ Nanofilms
}

\author{
Peng ZHU *, Zhen GUAN, Shuai FU, Shuangfei ZHAO, Ruiqi SHEN, Yinghua YE
}

School of Chemical Engineering, Nanjing University of Science and Technology, Nanjing210094, China

crossref http://dx.doi.org/10.5755/j01.ms.24.2.18266

Received 28 May 2017; accepted 16 October 2017

\begin{abstract}
Two types of energetic semiconductor bridges (ESCBs), with $3 \mu \mathrm{m}$ and $6 \mu \mathrm{m} \mathrm{Al} / \mathrm{MoO}_{3}$ energetic multilayer nanofilms integrated respectively, were prepared with microfabrication technique. The influence of $\mathrm{Al} / \mathrm{MoO}_{3}$ nanofilms thickness on the firing and initiation characteristics of ESCBs was investigated. Results show that critical firing time and critical firing energy of ESCBs do not change significantly. The flame size of SCB-Al/ $\mathrm{MoO}_{3}(6 \mu \mathrm{m})$ is twice than that of SCB$\mathrm{Al} / \mathrm{MoO}_{3}(3 \mu \mathrm{m})$ at $100 \mu \mathrm{s}$. Furthermore, the firing duration of $\mathrm{SCB}-\mathrm{Al} / \mathrm{MoO}_{3}(6 \mu \mathrm{m})$ is $540 \mu \mathrm{s}$, much higher than SCB$\mathrm{Al} / \mathrm{MoO}_{3}(3 \mu \mathrm{m}) 300 \mu \mathrm{s}$, which is very useful for the initiation of energetic materials. However, the contact and noncontact initiation of ESCBs on $\mathrm{HMX}-\mathrm{Al} / \mathrm{MoO}_{3}$ composite explosives show that the film thickness of $\mathrm{Al} / \mathrm{MoO}_{3}$ has the remarkable influence on the initiation ability of ESCBs. The results from experiments deepen the understanding of the influence of thickness of $\mathrm{Al} / \mathrm{MoO}_{3}$ nanofilms on the firing performance of $\mathrm{SCB}$, which is very meaningful for the initiation of energetic materials.

Keywords: $\mathrm{Al} / \mathrm{MoO}_{3}$ energetic multilayer nanofilms, energetic semiconductor bridge, firing performance, initiation performance.
\end{abstract}

\section{INTRODUCTION}

Semiconductor bridge (SCB) offers many potential advantages over conventional bridge wire ignition including increased safety by providing higher no-fire levels, lower firing energy, and faster response $[1,2]$. Beson and co-works from Sandia National Laboratories described SCB processing and experiments evaluating SCB operation in detail [1]. They found that the SCB produces a hot plasma that ignites explosives when driven with a short $(20 \mu \mathrm{s})$, low-energy pulse (less than $3.5 \mathrm{~mJ})$. The SCB device has been used in civilian and military equipments in recent years due to its excellent performances. Nevertheless, this kind of initiator shows some limitations due to its relatively low output energy. To improve its performance, integration of nanothermite on SCB is an effective way. Energetic semiconductor bridge (ESCB) is integrated with certain thickness energetic multilayer nanofilms on SCB. Nanothermite is a metastable intermolecular composites characterized by a particle size of its main constituent, a metal and a metal oxide, under 100 nanometers. As the mass transport mechanisms that slow down the burning rates of traditional thermites are not so important at these scales, the reactions become kinetically controlled and proceed much more quickly. Different types of nanothermites have been synthesized, such as mixed or arrested milling nanopowders $[3,4]$, nanostructured composites [5-10] and multilayer nanofilms [11-16].

For SCB applications, multilayer nanofilms are more attracting because they can be integrated directly onto SCB with magnetron sputtering. Such solutions do provide improvement in term of reliability $[17-20]$. However,

\footnotetext{
${ }^{*}$ Corresponding author. Tel.: +8615996265061.

E-mail address: zhupeng@njust.edu.cn (P. Zhu)
}

since multilayer nanofilms are highly reactive, SCB could be less safe for some applications. In order to solve the sensitive rising issue of $\mathrm{ESCB}$, negative temperature coefficient thermistor chip (NTC) was integrated in parallel connection in previous work [20,21]. After integrated with NTC, ESCB is compatible with existing firing sets used to drive SCB while withstanding electromagnetic interference and electrostatic discharge conditions.

However, there are few studies in the literature to evaluate the influence of multilayer nanofilms thickness on firing and initiation characteristics of ESCB, although this is very important for the practical applications. In this paper, two types of ESCB integrated with $3 \mu \mathrm{m}$ and $6 \mu \mathrm{m}$ $\mathrm{Al} / \mathrm{MoO}_{3}$ multilayer nanofilms were prepared with microfabrication technique, respectively. Firing and initiation characteristics of ESCBs were obtained by varied characterization.

\section{DESIGN AND PREPARATION OF $\mathrm{SCB}-\mathrm{Al} / \mathrm{MoO}_{3}$}

Fig. 1 shows the schematic diagram of $\mathrm{SCB}-\mathrm{Al} / \mathrm{MoO}_{3}$ chip. The device consists of six parts, namely, Si substrate (the thickness is $500 \mu \mathrm{m}$ ), $\mathrm{SiO}_{2}$ insulating layer (the thickness is $1 \mu \mathrm{m})$, SCB chip made from heavily n-type doped polysilicon, $\mathrm{Ti}(30 \mathrm{~nm}) / \mathrm{Au}(200 \mathrm{~nm})$ lands, $\mathrm{MoO}_{3}$ layer (the thickness is $150 \mathrm{~nm}$, used to insulate the $\mathrm{Al} / \mathrm{MoO}_{3}$ films and SCB chip) and $\mathrm{Al} / \mathrm{MoO}_{3}$ multilayer nanofilms (the total reactive surface is $1 \mathrm{~mm} \times 1 \mathrm{~mm}$ and the film thickness is $3 \mu \mathrm{m}$ and $6 \mu \mathrm{m})$. Each bilayer consists of $30 \mathrm{~nm} \mathrm{Al}$ and $45 \mathrm{~nm} \mathrm{MoO}_{3}$ so as to obtain a stoichiometric ratio. The resistance of SCB was designed as $1.3 \pm 0.1 \Omega$. The SCB bridge has two $\mathrm{V}$-type angles $\left(90^{\circ}\right)$ and the size is $380 \mu \mathrm{m}$ (width) $\times 80 \mu \mathrm{m}$ (length) $\times 2.5 \mu \mathrm{m}$ (thickness). The $\mathrm{SCB}-\mathrm{Al} / \mathrm{MoO}_{3}$ chip was 
fabricated on a silicon wafer using a combination of photolithography, sputtering deposition, and lift-off techniques $[19,20]$.

As shown in Fig. 2, SCB-Al/ $\mathrm{MoO}_{3}$ chip was mounted into the top groove of a ceramic plug with non-conductive epoxy resin. The external diameter of the ceramic plug is $6 \mathrm{~mm}$ and the height is $4.5 \mathrm{~mm}$. The Ti/Au lands of the SCB chip and the two pins of ceramic plug were connected together with gold wires whose diameter is $30 \mu \mathrm{m}$ and length is $2 \mathrm{~mm}$ by ultrasonic bonding technology. Silverfilled conductive epoxy was used to reinforce a connection between the plug pins and the gold contact pads on SCB.

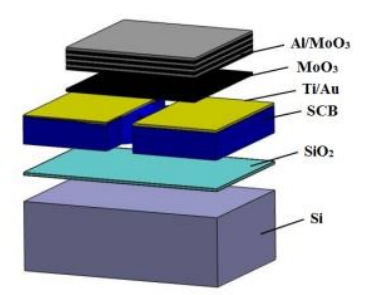

a

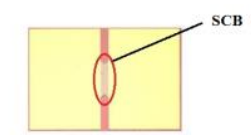

b

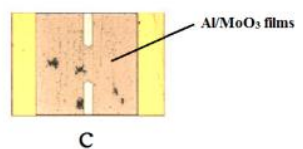

Fig. 1. a - a schematic exploded view of a $\mathrm{SCB}-\mathrm{Al} / \mathrm{MoO}_{3}$ chip; b-optical image of SCB chip; $c$-optical image of SCB$\mathrm{Al} / \mathrm{MoO}_{3}$ chip

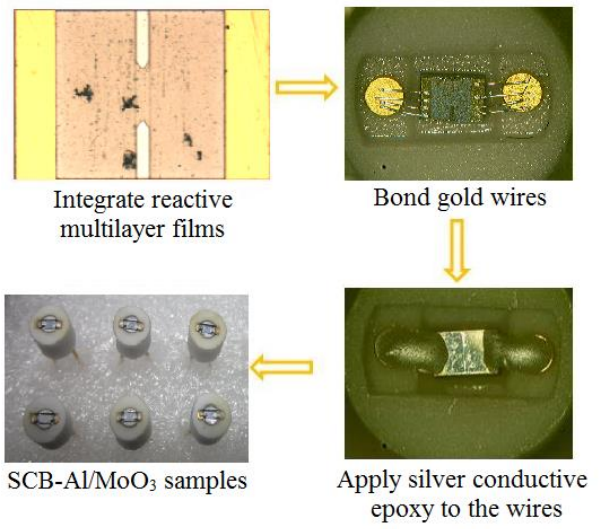

Fig. 2. Preparation schema and optical images of $\mathrm{SCB}-\mathrm{Al} / \mathrm{MoO}_{3}$

\section{3. $\mathrm{SCB}-\mathrm{Al} / \mathrm{MoO}_{3}$ FIRING CHARACTERIZATION}

The firing characterization was operated with a tantalum capacitor $(47 \mu \mathrm{F})$ firing circuit as shown in Fig. 3. Voltage and current were recorded with an oscilloscope (4-channel, LeCroy44Xs) during the tests. The digital switches were adopted in the firing circuit. A high-speed camera (HG-100 K) was used to observe the initiators as electrical power was applied. In the experiment, when switch 1 was closed, the capacitor was charged by the power supply. When switch 1 was disconnected and switch 2 was closed, the $\mathrm{SCB}-\mathrm{Al} / \mathrm{MoO}_{3}$ was initiated by capacitor discharging. The oscilloscope and high-speed video were triggered synchronously with the application of electrical power to the device. Multiple tests were performed with the discharge voltage ranging from $15 \mathrm{~V}$ to $45 \mathrm{~V}$ at $2.5 \mathrm{~V}$ increment. Under each identical condition, three samples of each kind of initiators were initiated, and then the results were averaged.

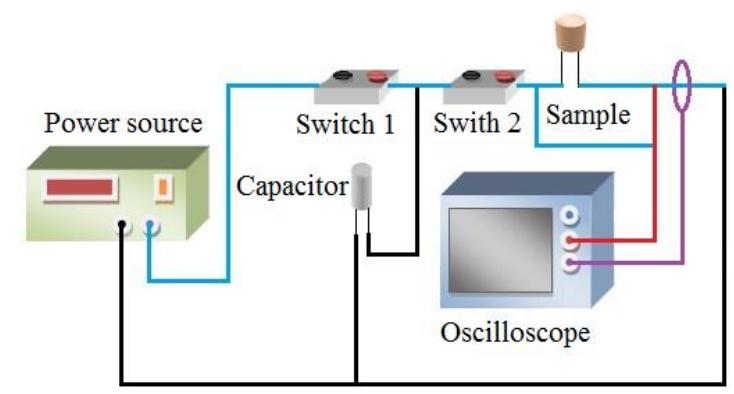

Fig. 3. Schematic drawing of the discharge circuit

\subsection{Definition of firing characteristic parameters}

In order to evaluate the influence of multilayer nanofilms thickness on firing performance, the characteristic parameters were defined firstly. Fig. 4 shows the variation of current, resistance and voltage along with the time under the discharge voltage in $47 \mu \mathrm{F} / 40 \mathrm{~V}$ of conventional SCB [20].

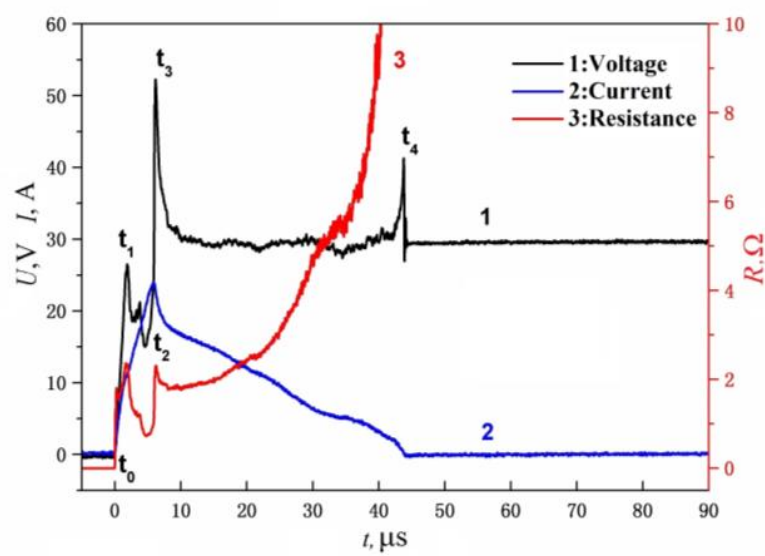

Fig. 4. Curves of current, voltage and resistance varied with time

The resistance of the bridge (get from the voltage divided by current) began to rise, which was seen with the increase of voltage across the bridge. Due to the negative temperature coefficient of SCB, whose resistance decreases roughly exponentially as their temperature increases. Once the bridge material was completely vaporized, the resistance increases promptly. The initial bump in the voltage wave was believed to be the onset of bridge melting $\left(t_{1}\right)$. After that, the voltage decreased dramatically to $t_{2}$ where was believed to be the end of melting. The second sudden increase in voltage signaled the onset of the plasma where the bridge material was entirely vaporized $\left(t_{3}\right)$. Because of the rapid increase in resistance during vaporizing, the current dropped off very rapidly from $t_{3}$ to the end of the current pulse $\left(t_{4}\right)$. Once the bridge material was completely vaporized, the current acted to the vapor and initiated the plasma discharge. The plasma-heating course was defined as the late time discharge which covered from $t_{3}$ to $t_{4}$. Notably, $t_{3}$ is the critical point that signals the onset of the plasma where the bridge material was entirely vaporized. Therefore, this point is also called critical firing time $\left(t_{\mathrm{c}}\right)$, and its electrical energy consumption is called critical firing energy $\left(E_{\mathrm{c}}\right)$. 


\subsection{Comparison and analysis of the critical firing time and critical firing energy for three kinds of initiators}

Fig. 5 shows the variations of critical firing time $\left(t_{c}\right)$ and critical firing energy $\left(E_{\mathrm{c}}\right)$ with discharge voltage for $\mathrm{SCB}, \mathrm{SCB}-\mathrm{Al} / \mathrm{MoO}_{3}(3 \mu \mathrm{m})$ and $\mathrm{SCB}-\mathrm{Al} / \mathrm{MoO}_{3}(6 \mu \mathrm{m})$. In Fig. 5 a $[20,21], E_{\mathrm{c}}$ was obtained by numeric integration of the power vs time trace, it was calculated from the following equation. It seems that the discharge voltage has a negligible effect on $E_{\mathrm{c}}$.

$$
E_{c}=\int_{t_{0}}^{t_{c}} U(t) I(t) d t
$$

As shown in Fig. 5 b, $t_{c}$ decreases with the potential, which is basically the same for the three samples. As well known that discharge time constant of a capacitor is within $3 \tau \sim 5 \tau(\tau=R C, R$ is the resistance of the initiator, $\mathrm{C}$ is the capacitance). The energy that the capacitor stores increases with the charging voltage rising up, so does the power applied on SCB in a certain time. Because $E_{\mathrm{c}}$ is constant, firing time decreases as the discharge voltage increases.
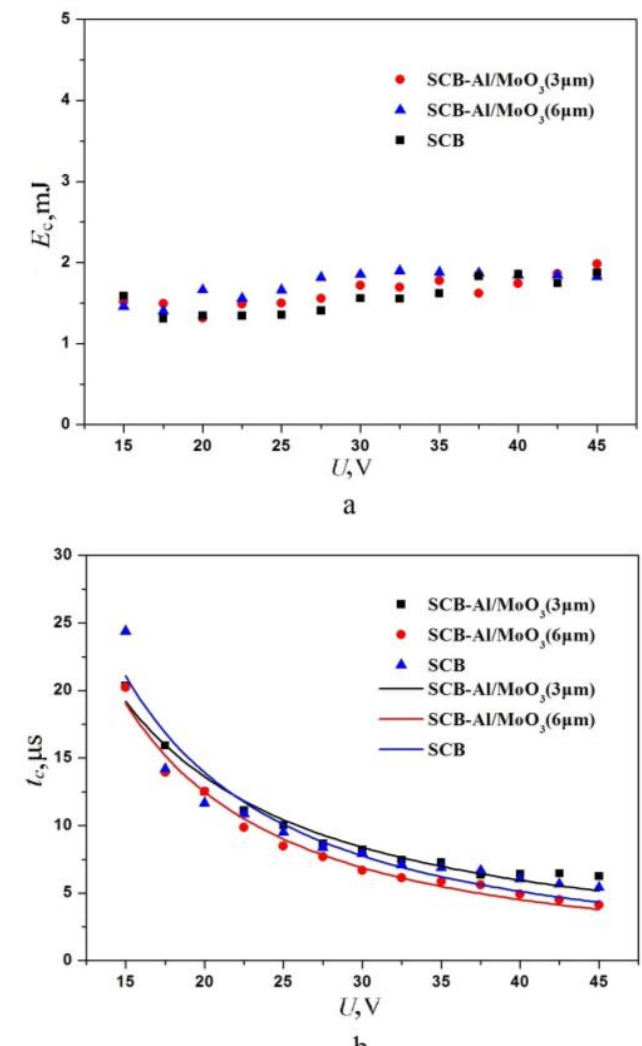

Fig. 5. Comparison of critical firing time and critical firing energy with discharge voltage: a-critical firing energy $\left(E_{\mathrm{c}}\right)$ vs Discharge voltage $(\mathrm{U}) ; \mathrm{b}$-critical firing time $\left(t_{\mathrm{c}}\right)$ vs Discharge voltage (U)

The results imply that $t_{\mathrm{c}}$ and $E_{\mathrm{c}}$ are only related to the size and structure of SCB in the process of electrical initiation. As far as a certain shape and size of SCB studied in this paper, it is believed that $E_{\mathrm{c}}$ is an inherent property of SCB. When the shape, size and the doping concentration of the SCB are confirmed, $E_{\mathrm{c}}$ of SCB tends to be a certain value, no matter if being covered with $\mathrm{Al} / \mathrm{MoO}_{3}$ films or not. Therefore, it is demonstrated that $\mathrm{Al} / \mathrm{MoO}_{3}$ multilayer nanofilms have no distinct influence on the $t_{\mathrm{c}}$ and $E_{\mathrm{c}}$ of SCB.

\subsection{High-speed photography analysis of the firing performance}

A high-speed camera was used to analysis the firing performance of the three kinds of initiators. It was set to record at 50.000 frames per second. Fig. 6 depicts the firing process of three samples discharged in $40 \mathrm{~V}$. The interval between adjoining pictures is $20 \mu \mathrm{s}$.

As shown in Fig. 6 a, SCB heats up and melts at first. At $\sim 20 \mu \mathrm{s}$, the plasma reaches its maximum and after that plasma becomes weaker and weaker. The whole firing process lasts for $\sim 80 \mu \mathrm{s}$. For SCB-Al/ $/ \mathrm{MoO}_{3}(6 \mu \mathrm{m})$ and $\mathrm{SCB}-\mathrm{Al} / \mathrm{MoO}_{3}(3 \mu \mathrm{m})$, the plasma at $\sim 20 \mu \mathrm{s}$ is almost the same. After that, plasma begins to increase and reaction between $\mathrm{Al}$ and $\mathrm{MoO}_{3}$ is initiated. The violent thermite reaction gives out high temperature plasma and products. As shown in Fig. $6 \mathrm{~b}$, at $\sim 60 \mu \mathrm{s}, \mathrm{SCB}-\mathrm{Al} / \mathrm{MoO}_{3}(3 \mu \mathrm{m})$ generates a large quantity of ejected product particles and the size of combustion flame reaches the maximum of the whole process. After that, the combustion becomes weak, and the reaction dies away. In Fig. 6 c, comparably, a fierce combustion happens and a brighter flame is generated by $\mathrm{SCB}-\mathrm{Al} / \mathrm{MoO}_{3}(6 \mu \mathrm{m})$. It is believed that the flame size of $\mathrm{SCB}-\mathrm{Al} / \mathrm{MoO}_{3}(6 \mu \mathrm{m})$ is twice than that of $\mathrm{SCB}-\mathrm{Al} / \mathrm{MoO}_{3}(3 \mu \mathrm{m})$ at $\sim 100 \mu \mathrm{s}$. Furthermore, the firing duration of SCB-Al/ $/ \mathrm{MoO}_{3}(6 \mu \mathrm{m})$ is $\sim 540 \mu \mathrm{s}$, much higher than $\mathrm{SCB}-\mathrm{Al} / \mathrm{MoO}_{3}(3 \mu \mathrm{m}) \sim 300 \mu \mathrm{s}$, which is very useful for the initiation of energetic materials.
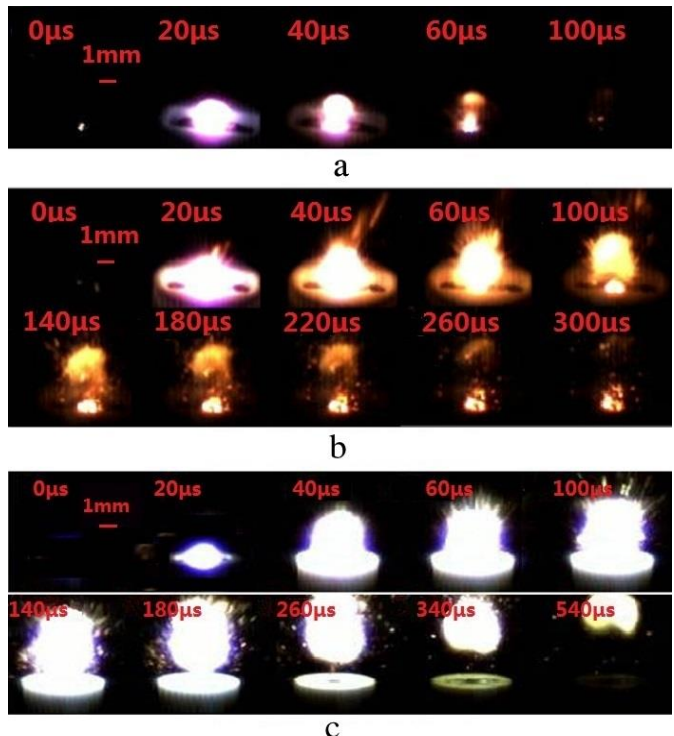

Fig. 6. High-speed images of firing process discharged in $40 \mathrm{~V}$ : $\mathrm{a}-\mathrm{SCB} ; \quad \mathrm{b}-\mathrm{SCB}-\mathrm{Al} / \mathrm{MoO}_{3}(3 \mu \mathrm{m}) ; \quad \mathrm{c}-\mathrm{SCB}-\mathrm{Al} / \mathrm{MoO}_{3}$ $(6 \mu \mathrm{m})$

\section{4. $\mathrm{SCB}-\mathrm{Al} / \mathrm{MoO}_{3}$ INITIATION \\ CHARACTERIZATION ON HMX-Al/MoO $\mathrm{MO}_{3}$ COMPOSITE EXPLOSIVES}

The initiation characterization of $\mathrm{SCB}-\mathrm{Al} / \mathrm{MoO}_{3}$ was operated with $\mathrm{HMX}-\mathrm{Al} / \mathrm{MoO}_{3}$ composite explosives. It was made of stoichiometric $\mathrm{Al} / \mathrm{MoO}_{3}$ nanopowders and nano-HMX, and its sensitivity could be adjusted by 
varying the mass fraction of nano-HMX. Nano-Al has $50 \mathrm{~nm}$ average particle size, $80 \mathrm{wt} \%$ active metal content, and nano- $\mathrm{MoO}_{3}$ has $100 \mathrm{~nm}$ average particle size with 99 wt.\% purity (Aladdin Industrial Corporation, China), and nano-HMX was home-made with 300nm average particle size. For $\mathrm{HMX}-\mathrm{Al} / \mathrm{MoO}_{3}$ composite explosives, after weighing the nano- $\mathrm{HMX}$ and $\mathrm{Al} / \mathrm{MoO}_{3}$ components, the mixed powders were dispersed into hexane and the suspensions were sonicated for $30 \mathrm{~min}$ to improve dispersibility and homogeneity. To prevent the oxidation of $\mathrm{Al}$ nanoparticles at elevated temperatures, the mixture was obtained by vacuum drying for $2 \mathrm{~h}$ at $50{ }^{\circ} \mathrm{C}$.

In this characterization, $\mathrm{HMX}-\mathrm{Al} / \mathrm{MoO}_{3}$ composite explosives were composed of $50 \mathrm{wt} . \%, 60 \mathrm{wt} \%$, $65 \mathrm{wt} . \%$, and $70 \mathrm{wt} . \%$ fine nano-HMX particles (50 wt.\%, $40 \mathrm{wt} . \%$, $35 \mathrm{wt} . \%$, and $30 \mathrm{wt} . \%$ mixed $\mathrm{Al} / \mathrm{MoO}_{3}$ nanopowders, respectively). Then, they were pressed into stainless charge holder (outer diameter $6 \mathrm{~mm}$, inner diameter $3 \mathrm{~mm}$, height $3 \mathrm{~mm}$ ) with $20 \mathrm{MPa}$ pressure. Both contact initiation and non-contact initiation were operated for better comparison.

\subsection{Contact initiation of SCB-Al/MoO $/ \mathrm{O}_{3}$ on $\mathrm{HMX}$ - $\mathrm{Al} / \mathrm{MoO}_{3}$ composite explosives}

The contact initiation device was showed in Fig. 7. It mainly consists of a $\mathrm{SCB}-\mathrm{Al} / \mathrm{MoO}_{3}$ initiator, a rubber seal, six bolts closed stainless vessel and an explosion venting. It was found that $\mathrm{HMX}-\mathrm{Al} / \mathrm{MoO}_{3}$ can be initiated by both SCB and ESCB when the ratio of nano-HMX is $50 \mathrm{wt} . \%$, however, it becomes too insensitive to be initiated by the any of the SCB when the ratio of nano-HMX increases to $70 \mathrm{wt} . \%$. Therefore, the nano-HMX at the ratio of $65 \mathrm{wt} . \%$ and $60 \mathrm{wt} . \%$ were characterized in detail, and the results are showed in Table 1. It should be noted that the discharge voltage can't exceed the upper limit of $47 \mu \mathrm{F} / 60 \mathrm{~V}$ of tantalum capacitor.

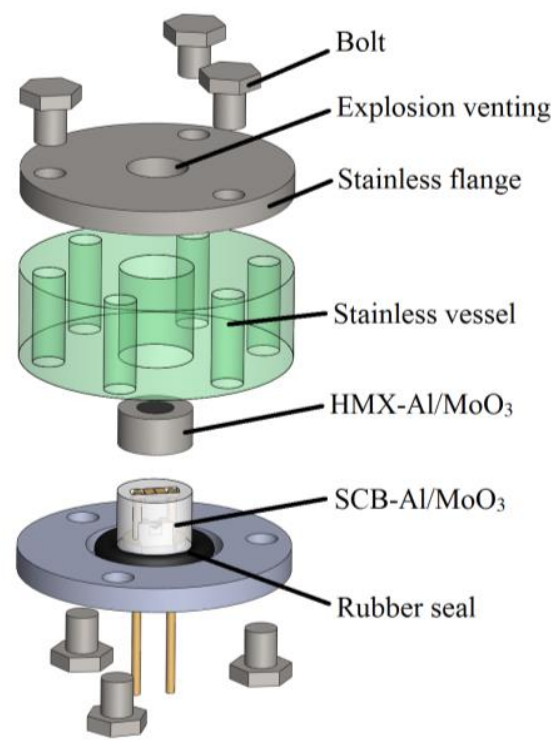

Fig. 7. Schematic diagram of the contact initiation device of $\mathrm{HMX}-\mathrm{Al} / \mathrm{MoO}_{3}$

As shown in Table 1, SCB can't initiate HMX$\mathrm{Al} / \mathrm{MoO}_{3}$ even discharged in $47 \mu \mathrm{F} / 60 \mathrm{~V}$ when the ratio of nano-HMX is $65 \mathrm{wt} . \%$, but for $\mathrm{SCB}-\mathrm{Al} / \mathrm{MoO}_{3}(3 \mu \mathrm{m})$ and $\mathrm{SCB}-\mathrm{Al} / \mathrm{MoO}_{3}(6 \mu \mathrm{m})$, it is successfully to initiate $\mathrm{HMX}-$
$\mathrm{Al} / \mathrm{MoO}_{3}$ at $47 \mu \mathrm{F} / 24.5 \mathrm{~V}$ and $47 \mu \mathrm{F} / 17 \mathrm{~V}$, respectively. Also, it is obviously that the required threshold discharge voltages decrease with the increasing film thickness. In addition, $\mathrm{HMX}-\mathrm{Al} / \mathrm{MoO}_{3}$ becomes more sensitive along with nano-HMX ratio decreases to $60 \mathrm{wt} . \%$, so that SCB can initiate it at $47 \mu \mathrm{F} / 32.5 \mathrm{~V}$. In comparison, $47 \mu \mathrm{F} / 17 \mathrm{~V}$ is enough for both $\mathrm{SCB}-\mathrm{Al} / \mathrm{MoO}_{3}(3 \mu \mathrm{m})$ and SCB$\mathrm{Al} / \mathrm{MoO}_{3}(6 \mu \mathrm{m})$.

Table 1. Contact initiation results of $\mathrm{HMX}-\mathrm{Al} / \mathrm{MoO}_{3}$ with 65 wt. $\%$ and $60 \mathrm{wt} . \%$ nano-HMX

\begin{tabular}{|c|c|c|c|}
\hline Explosive & Initiator & $\begin{array}{l}\text { Discharge } \\
\text { voltage, } \mathrm{V}\end{array}$ & Phenomenon \\
\hline \multirow{3}{*}{$\begin{array}{c}\mathrm{HMX}- \\
\mathrm{Al} / \mathrm{MoO}_{3} \\
(65 \text { wt. } \%)\end{array}$} & SCB & 60 & None fire \\
\hline & $\begin{array}{c}\text { SCB-Al/MoO } 3 \\
(3 \mu \mathrm{m})\end{array}$ & 24.5 & fired \\
\hline & $\begin{array}{c}\mathrm{SCB}-\mathrm{Al} / \mathrm{MoO}_{3} \\
(6 \mu \mathrm{m})\end{array}$ & 17.0 & fired \\
\hline \multirow{3}{*}{$\begin{array}{c}\mathrm{HMX}^{-} \\
\mathrm{Al}^{2} \mathrm{MoO}_{3} \\
(60 \text { wt. } \%)\end{array}$} & SCB & 32.5 & fired \\
\hline & $\begin{array}{c}\text { SCB-Al/MoO } 3 \\
(3 \mu \mathrm{m})\end{array}$ & 17.0 & fired \\
\hline & $\begin{array}{c}\mathrm{SCB}-\mathrm{Al} / \mathrm{MoO}_{3} \\
(6 \mu \mathrm{m})\end{array}$ & 17.0 & fired \\
\hline
\end{tabular}

\subsection{Non-contact initiation of $\mathrm{SCB}-\mathrm{Al} / \mathrm{MoO}_{3}$ on $\mathrm{HMX}-\mathrm{Al} / \mathrm{MoO}_{3}$ composite explosives}

The non-contact initiation device (Fig. 8) is almost the same as contact initiation device besides several gap rings for achieving initiation gap. A series of tests were operated to investigate the non-contact initiation ability for relatively sensitive $\mathrm{HMX}-\mathrm{Al} / \mathrm{MoO}_{3}$ (60 wt.\% nano-HMX). Also, it should be noted that the discharge voltage can't exceed the upper limit of $47 \mu \mathrm{F}$ tantalum capacitor $60 \mathrm{~V}$. Table 2 shows the results under the varied gaps. U $0.1 \%$, $\mathrm{V}, \mathrm{U} 50 \%, \mathrm{~V}$ and $\mathrm{U} 99.9 \%, \mathrm{~V}$ represent the required discharge voltages where the initiation probabilities for $\mathrm{HMX}-\mathrm{Al} / \mathrm{MoO}_{3}$ is $0.1 \%, 50 \%$ and $99.9 \%$, respectively. For three kinds of initiators, it is obviously that the noncontact initiation capability is enhanced greatly along with the increasing thickness of $\mathrm{Al} / \mathrm{MoO}_{3}$ nanofilms.

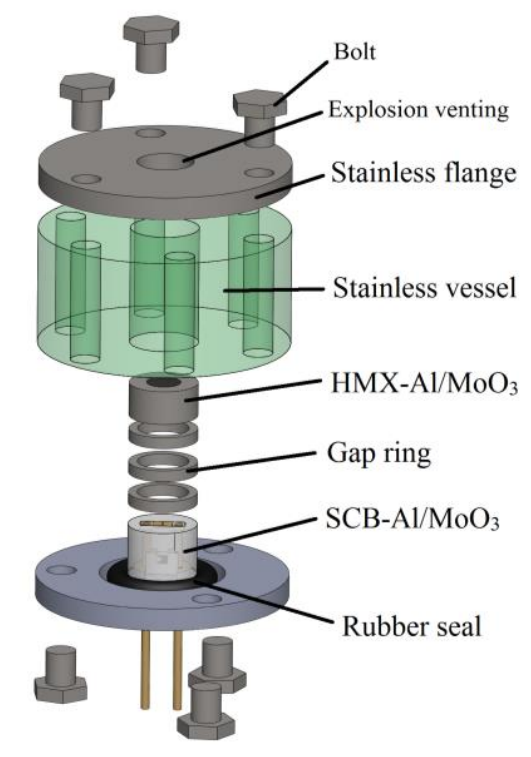

Fig. 8. Schematic diagram of the non-contact initiation device of $\mathrm{HMX}-\mathrm{Al} / \mathrm{MoO}_{3}$ 
Table 2. Non-contact initiation results of $\mathrm{HMX}-\mathrm{Al} / \mathrm{MoO}_{3}$ with 60 wt. $\%$ nano-HMX

\begin{tabular}{|c|c|c|c|c|c|}
\hline Explosive & Initiator & $\begin{array}{c}\text { Gap, } \\
\text { mm }\end{array}$ & $\begin{array}{c}\text { U0.1\%, } \\
\text { V }\end{array}$ & $\begin{array}{c}\mathrm{U} 50 \%, \\
\mathrm{~V}\end{array}$ & $\begin{array}{c}\mathrm{U} 99.9 \% \\
\mathrm{~V}\end{array}$ \\
\hline \multirow{3}{*}{$\begin{array}{c}\mathrm{HMX}- \\
\mathrm{Al} / \mathrm{MoO}_{3}\end{array}$} & \multirow{3}{*}{ SCB } & 1.45 & 28.5 & 31.25 & 35.0 \\
\hline & & 2.45 & 42.5 & 43.75 & 45.0 \\
\hline & & 3.45 & 60.0 & - & - \\
\hline \multirow{3}{*}{$\begin{array}{c}\mathrm{HMX}- \\
\mathrm{Al} / \mathrm{MoO}_{3}\end{array}$} & \multirow{3}{*}{$\begin{array}{c}\text { SCB- } \\
\mathrm{Al}^{2} \mathrm{MoO}_{3} \\
(3 \mu \mathrm{m})\end{array}$} & 8.45 & 15.0 & 17.5 & 20.0 \\
\hline & & 9.45 & 31.5 & 36.75 & - \\
\hline & & 10.45 & 60.0 & - & - \\
\hline \multirow{3}{*}{$\begin{array}{c}\mathrm{HMX}- \\
\mathrm{Al} / \mathrm{MoO}_{3}\end{array}$} & \multirow{3}{*}{$\begin{array}{c}\text { SCB- } \\
\mathrm{Al} / \mathrm{MoO}_{3} \\
(6 \mathrm{um})\end{array}$} & 11.45 & 15.0 & 17.5 & 20.0 \\
\hline & & 12.45 & 22.5 & 56.5 & - \\
\hline & & 13.45 & 60.0 & - & - \\
\hline
\end{tabular}

\section{CONCLUSIONS}

In this paper, the firing and initiation performance of $\mathrm{SCB}, \mathrm{SCB}-\mathrm{Al} / \mathrm{MoO}_{3}(3 \mu \mathrm{m})$ and $\mathrm{SCB}-\mathrm{Al} / \mathrm{MoO}_{3}(6 \mu \mathrm{m})$ were studied and compared. The test results indicate the following characteristics.

1. The critical firing time $\left(t_{\mathrm{c}}\right)$ and the critical firing energy $\left(E_{\mathrm{c}}\right)$ are independent of the thickness of $\mathrm{Al} / \mathrm{MoO}_{3}$ films, and only related to the inherent properties of SCB.

2. The energy released by nanoscale exothermic reaction of $\mathrm{Al} / \mathrm{MoO}_{3}$ nanofilms enhances the plasma size and duration, which is very meaningful especially for the non-contact initiation of energetic materials.

In conclusion, the results from experiments deepen the understanding of the firing and initiation characteristics of ESCB integrated with varied thicknesses of $\mathrm{Al} / \mathrm{MoO}_{3}$ nanofilms.

\section{Acknowledgments}

This work was supported by the Natural Science Foundation of Jiangsu Province of China (No. BK20151486).

\section{REFERENCES}

1. Benson, D.A., Larsen, M.E., Renlund, A.M., Trott, W.M., Bickes, R.W. Semiconductor Bridge: A Plasma Generator for the Ignition of Explosives Journal of Applied Physics 62 (5) 1987: pp. $1622-1632$. https://doi.org/10.1063/1.339586

2. Msrtinez, M.J., Baer, M.R. Microconvective Heating of Granular Explosives by a Semiconductor Bridge, Technical Report, 1989.

3. Rossi, C., Zhang, K., Estève, D., Alphonse, P., Tailhades, P., Vahlas, C. Nanoenergetic Materials for MEMS: A Review Journal of Microelectromechanical Systems 16 (4) 2007: pp. 919-931.

https://doi.org/10.1109/JMEMS.2007.893519

4. Dreizin, E.L. Metal-based Reactive Nanomaterials Progress in Energy and Combustion Science 35 (2) 2009: pp. 141-167. https://doi.org/10.1016/j.pecs.2008.09.001

5. Zhou, X., Torabi, M., Lu, J., Shen, R., Zhang, K. Nanostructured Energetic Composites: Synthesis, Ignition/Combustion Modeling, and Applications ACS Applied Materials \& Interfaces 6(5) 2014: pp. $3058-3074$. https://doi.org/10.1021/am4058138

6. Zhang, K., Rossi, C., Ardila Rodriguez, G.A. Development of a Nano-Al/CuO Based Energetic Material on Silicon Substrate Applied Physics Letters 91 (11) 2007: pp. 43-H01. https://doi.org/10.1063/1.2785132
7. Zhang, K., Yang, Y., Pun, E.Y., Shen, R. Local and CMOScompatible Synthesis of $\mathrm{CuO}$ Nanowires on a Suspended Microheater on a Silicon Substrate Nanotechnology 21 (22) 2010: pp. 235602-235608. https://doi.org/10.1088/0957-4484/21/23/235602

8. Zhou, X., Xu, D., Zhang, Q., Lu, J., Zhang, K. Facile Green in Situ Synthesis of $\mathrm{Mg} / \mathrm{CuO}$ Core/shell Nanoenergetic Arrays with a Superior Heat-release Property and Long-term Storage Stability Acs Applied Materials \& Interfaces 5 (13) 2013: pp. $7641-7646$. https://doi.org/10.1021/am401955u

9. Qiao, Z., Xu, D., Nie, F., Yang, G., Zhang, K. Controlled Facile Synthesis, Growth Mechanism, and Exothermic Properties of Largearea $\mathrm{Co}_{3} \mathrm{O}_{4}$ Nanowalls and Nanowires on Silicon Substrates Journal of Applied Physics 112 (1) 2012: pp. 746-749. https://doi.org/10.1063/1.4731798

10. Zhang, K., Rossi, C., Tenailleau, C., Alphonse, P. Aligned Threedimensional Prismlike Magnesium Nanostructures Realized onto Silicon Substrate Applied Physics Letters 92 (6) 2008: pp. 063123-063126.

11. Rogachev, A.S. Exothermic Reaction Waves in Multilayer Nanofilms Russian Chemical Reviews 77 (1) 2008: pp. 22-37. https://doi.org/10.1070/RC2008v077n01ABEH003748

12. Blobaum, K.J., Reiss, M.E., Plitzko, J.M., Weihs, T.P. Deposition and Characterization of a Self-Propagating $\mathrm{CuOx} / \mathrm{Al}$ thermite Reaction In A Multilayer Foil Geometry Journal of Applied Physics 94 (5) 2003: pp. 2915-2922. https://doi.org/10.1063/1.1598296

13. Blobaum, K.J., Wagner, A.J., Plitzko, J.M., Van Heerden, D., Fairbrother, D.H., Weihs, T.P. Investigating the Reaction Path And Growth Kinetics in CuOx/Al Multilayer Foils Journal of Applied Physics 94 (5) 2003: pp. 2923-2929. https://doi.org/10.1063/1.1598297

14. Petrantoni, M., Rossi, C., Salvagnac, L., Conédéra, V., Estève, A., $\quad$ Tenailleau, C., Alphonse, $P$., $\quad$ Chabal, Y.J. Multilayered $\mathrm{Al} / \mathrm{CuO}$ Thermite Formation by Reactive Magnetron Sputtering: Nano Versus Micro Journal of Applied Physics 108 (8) 2010: pp. 084323-084328 https://doi.org/10.1063/1.3498821

15. Manesh, N.A., Basu, S., Kumar, R. Experimental Flame Speed in Multi-Layered Nano-Energetic Materials Combustion \& Flame 157 (3) 2010: pp. $476-480$. https://doi.org/10.1016/j.combustflame.2009.07.011

16. Manesh, N.A., Basu, S., Kumar, R. Modeling of a Reacting Nanofilm on a Composite Substrate Energy 36 (3) 2011: pp. $1688-1697$. https://doi.org/10.1016/j.energy.2010.12.061

17. Taton, G., Lagrange, D., Conedera, V., Renaud, L., Rossi1, C. Micro-chip Initiator Realized by Integrating $\mathrm{Al} / \mathrm{CuO}$ Multilayer Nanothermite on Polymeric Membrane Journal of Micromechanics \& Microengineering 23 (10) 2013: pp. 105009-105016. https://doi.org/10.1088/0960-1317/23/10/105009

18. Zhang, K., Rossi, C., Petrantoni, M. A Nano Initiator Realized by Integrating $\mathrm{Al} / \mathrm{CuO}$-Based Nanoenergetic Materials With a $\mathrm{Au} / \mathrm{Pt} / \mathrm{Cr}$ Microheater Journal of Microelectromechanical Systems 17 (4) 2008: pp. 832-836.

19. Zhu, P., Shen, R., Ye, Y., Fu, S., Li, D. Characterization of $\mathrm{Al} / \mathrm{CuO}$ Nanoenergetic Multilayer Films Integrated with Semiconductor Bridge for Initiator Applications Journal of Applied Physics 113 (18) 2013: pp. 184505-184505-5. https://doi.org/10.1063/1.4804315

20. Zhu, P., Jiao, J., Shen, R., Ye, Y., Fu, S., Li, D. Energetic Semiconductor Bridge Device Incorporating $\mathrm{Al} / \mathrm{MoOx}$ Multilayer Nanofilms and Negative Temperature Coefficient Thermistor Chip Journal of Applied Physics 115 (19) 2014: pp. 194502-1945025 https://doi.org/10.1063/1.4876264

21. Xu, J., Tai, Y., Ru, C., Dai, J., Shen, Y., Ye, Y., Shen, R., Fu, S. Characteristic of Energetic Semiconductor Bridge Based on $\mathrm{Al} / \mathrm{MoOx}$ Energetic Multilayer Nanofilms with Different Modulation Periods Journal of Applied Physics 121 (11) 2017: pp. $113301-11330$. https://doi.org/10.1063/1.4978371 